\title{
Prevalence and Characteristics of Diabetic Polyneuropathy in Passo Fundo, South of Brazil
}

\begin{abstract}
Purposes: The aim of the study was to investigate the prevalence of peripheral diabetic neuropathy (PDN) and associated characteristics among type 2 diabetic mellitus (DM2) patients in Passo Fundo, a city on Southern Brazil. Basic procedures: A cross-sectional study was conducted with 340 patients with type 2 diabetes mellitus. Tests were performed to evaluate vibration (tuning fork), light touch (10-g monofilament), temperature, and pain (pinprick) sensations, as well as ankle reflexes and heel walking. The condition was classified as peripheral diabetic neuropathy when results in at least three of these tests were negative. The electrically induced Hoffmann reflex test was performed in a group of patients to define the criterion standard used in the assessment of clinical examination sensibility in the diagnosis of neuropathy. Sensitivity was $83 \%$, specificity, $91 \%$, positive predictive value, $63 \%$, and negative predictive value, $90 \%$. The monofilament, pinprick and deep tendon reflex were the most accurate tests in the diagnosis of neuropathy. Main findings: Seventy-five patients $(22.1 \%)$ had peripheral diabetic neuropathy, nephropathy in $29.5 \%$ and retinopathy in $28.8 \%$. Conclusions: Logistic regression revealed that only duration of diabetes, creatinine and glycated hemoglobin concentrations were significantly associated with neuropathy. (Arq Bras Endocrinol Metab 2007;51/6:987-992)
\end{abstract}

Keywords: Type 2 diabetes mellitus; Diabetic neuropathy; Diabetic complications

\section{RESUMO}

Prevalência e Características da Polineuropatia Diabética em Passo Fundo, Sul do Brasil.

Propósito: O objetivo deste estudo foi investigar a prevalência da neuropatia diabética periférica (NDP) e características associadas entre pacientes com diabetes melito tipo 2 (DM2) na cidade de Passo Fundo, sul do Brasil. Procedimentos básicos: Um estudo de corte foi realizado com 340 pacientes portadores de DM2. Testes foram conduzidos a fim de avaliar sensações de vibração (diapasão), de toque leve (monofilamento $10 \mathrm{~g}$ ), de temperatura e de dor (agulha), bem como reflexos do tornozelo e caminhar com os calcanhares. A condição foi classificada como NDP quando os resultados em pelo menos três desses testes foram negativos. O teste reflexo de Hoffman induzido eletricamente foi conduzido em um grupo de pacientes a fim de determinar o critério padrão usado na avaliação da sensibilidade do exame clínico no diagnóstico de neuropatia. A sensibilidade foi de $83 \%$, especificidade, $91 \%$, valor preditivo positivo, $63 \%$ e valor preditivo negativo, $90 \%$. O teste do monofilamento, a dor e o reflexo do tendão foram os mais precisos no diagnóstico de neuropatia. Principais achado: Setenta e cinco pacientes $(22,1 \%)$ foram diagnosticados com NDP, nefropatia em 29,5\% e retinopatia em $28,8 \%$. Conclusões: Regressão logística revelou que somente a duração do diabetes e as concentrações de creatinina e hemoglobina glicada foram significativamente associados à neuropatia. (Arq Bras Endocrinol Metab 2007;51/6:987-982)

Descritores: Diabetes mellitus tipo 2; Neuropatia diabética; Complicações diabéticas

\section{artigo original}

\author{
GláUCIA SARTURI TRES \\ HUGO R. KURTZ LISBÔA \\ ROGER SYLLOS \\ luis Henrique Canani \\ JORGE LUIZ GROSS
}

School of Medicine, University of Passo Fundo (GCT \& HRKL) and Institute of Ophthalmology of Passo Fundo (RS), Passo Fundo, RS; and Endocrinology Service, Hospital de Clínicas of Porto Alegre (LHC \& JLG), Porto Alegre, RS.

Recebido em 14/08/06

Revisado em 11/01/07

Aceito em 23/01/07 
$\mathrm{D}$ IABETES MELLITUS (DM) IS A chronic disorder of the metabolism of glucose, lipids and proteins caused by a defect in insulin action or secretion. This metabolic disorder is responsible for chronic complications that affect macro and microcirculation (1). The manifestations of microvascular complications are more frequently found in the eyes, kidneys, and nerves, and those of macrovascular disease, in heart, brain, and leg arteries (2-4).

As DM prevalence has risen from $25 \%$ to $50 \%$ in Latin America, affecting $4-16 \%$ of the population, an increase in the number of such complications is expected (4). The prevalence of DM among adults in Brazil is $7.6 \%(5)$.

The damage to nerves in DM has been assumed to be a result of the interaction of metabolic defects complicated by vasa nervorum abnormalities. Neuropathic disorders may affect both somatic and autonomic nervous functions (6). In peripheral nerves such injuries cause loss of protective sensation impairing patient's ability to perceive incipient or even apparent ulcerations in the feet that is considered a main risk factor for amputation (7).

In Pirart's classic study, a 7.5\% neuropathy prevalence rate at the time of diagnosis and a linear prevalence increase of about $1.7 \%$ per year were found. This rate was $20 \%$ to $30 \%$ after 10 to 15 years from diagnosis, and reached $50 \%$ after 25 years (8). A population-based study conducted in France with DM2 patients reported that $37 \%$ of the patients had at least one chronic complication. In another population-based study conducted in England, neuropathy was found in $42 \%$ of the patients (9).

The frequency of neuropathy may vary according to the criteria used for diagnosis. The most prevalent form of diabetic neuropathy is sensory polyneuropathy (PNP) (10).

According to the Neurodiab Executive Committee, PNP affects at least $30 \%$ of patients with DM (11). Although neuropathy is a common complication of DM, it has not been studied as often as macrovascular complications or retinopathy and nephropathy (12).

The purposes of this study were to evaluate the prevalence of PND using a sensitive clinical method of diagnosis, and to identify factors associated with the development of this complication in Passo Fundo, South of Brazil.

\section{MATERIAL AND METHODS}

A cross-sectional study was conducted with 340 patients with DM2 defined according to WHO criteria. Patients enrolled in the study were consecutively seen at the Outpatient Diabetes Clinic of Hospital São Vicente de Paulo, Passo
Fundo, Brazil, from 2001 to 2002 . This city has 170,000 inhabitants and lies in a semi tropical region in the southern state of Brazil. The ethnic background is European, predominantly Portuguese, German, and Italian immigrants.

The Michigan Neuropathy Screening Instrument (MNSI), a 15-item questionnaire, was applied to access the presence of symptoms of neuropathy (13), and at physical examination six neurological tests were performed to evaluate sensation, deep reflexes, and force. Sensation was tested on the dorsum and tip of the first toe. A 10-gram SemmesWeinsten monofilament was used to test light touch, pinprick to test pain sense, 128-cycle tuning fork for vibration sense, and a cylinder with different temperatures for temperature sense. Deep tendon reflex was tested by striking the Achilles tendon with a reflex hammer. Muscle strength was tested by asking the patient to walk on heels. Neuropathy was diagnosed when three or more tests were negative.

Exclusion criteria were history of nerve root compression, hypothyroidism, or use of drugs that may cause peripheral neuropathy.

Hoffmann reflex recordings were obtained from a group of 40 patients, half with and half without neuropathy on physical examination. A Nihon-Kohden Neuropack ${ }^{\circledR}$ electromyograph was used. This test provides latency and amplitude of response of a peripheral nerve to an electrical stimulus of increasing intensity applied to the tibial nerve in the leg, and it identifies axonal, demyelinating, or combined forms of neuropathy. An individual with normal H-reflex will rarely have neuropathy (14). Diabetic neuropathy was diagnosed if any abnormal nerve conduction values were found. The Hoffmann reflex was used as the gold standard criterion to test the neurological examination and to check the sensitivity and specificity of clinical examination.

Patients answered a standard questionnaire about age, sex, and ethnicity, known duration of DM, DM treatment, and smoking habits. Smokers were defined as those who smoked at the time of the study or who had smoked for one year or more and who had not quit for at least 6 months before the evaluation. Patients were weighed in light clothing and without shoes; height was measured, and body mass index (BMI) was calculated as weight $/$ height ${ }^{2}\left(\mathrm{~kg} / \mathrm{m}^{2}\right)$. Waist circumference was measured at the narrowest point, and hip circumference, at the widest point; waist-to-hip ratio (WHR) was calculated. Sitting blood pressure was measured twice after a 10-minute rest, using a standard aneroid sphygmomanometer (phases I and V of Korotkoff sounds). Hypertension was diagnosed when blood pressure was $\geq 140 / 90 \mathrm{mmHg}$, or when the patient was taking antihypertensive drugs. Coronary artery disease was defined as the presence of angina or possible infarct according to WHO Cardiovascular Questionnaire (15) and/or abnormalities compatible with ischemia or necrosis on resting ECG (Minnesota code): Q and QS codes (1.1-2, 1.3); junctional ST segment and ST segment depression (4.1-4); T-wave abnormalities (5.1-3) and left bundle branch block (7.1) (15).

A trained ophthalmologist conducted the eye examinations using indirect ophthalmoscopy with dilation of pupils. Diabetic retinopathy (DR) was graded as: 1) no signs 
of DR, 2) non-proliferative DR (microaneurysms, hemorrhage, and hard exudates), or 3 ) proliferative DR (new blood vessels and/or scar tissue growing into the vitreous). Peripheral vascular disease (PVD) was diagnosed in the presence of intermittent claudication assessed according to the WHO questionnaire for cardiovascular disease (15), and/or of medial or posterior tibial pulse.

Glucose was measured by a glucose oxidase method, glycated hemoglobin $\left(\mathrm{HbA}_{\mathrm{lc}}\right)$ by high-pressure liquid chromatography (HPLC, Merck-Hitachi L-9100 glycated hemoglobin analyzer; reference range: 4.7-6.0\%; Merck, Darmstadt, Germany), creatinine by Jaffé's reaction, cholesterol and triglycerides by enzymatic colorimetric method, and HDL cholesterol by the direct method; LDL cholesterol was estimated by the Friedewald equation (LDL $=$ total cholesterol - [tryglicerides $/ 5+$ HDL] $)$.

Albuminuria was measured by immunoturbidimetry, Cobas Mina Roche ${ }^{\circledR}$, in a random urine sample. Protein loss was classified into three groups according to the presence of albumin in the urine sample: normal albuminuria $=$ up to 16 $\mathrm{mg} / \mathrm{L}$; microalbuminuria $=$ from 17 to $176 \mathrm{mg} / \mathrm{dL}$; and macroalbuminuria $=$ more than $176 \mathrm{mg} / \mathrm{dL}(16)$.

Renal failure was defined as creatinine concentrations higher than $1.99 \mathrm{mg} / \mathrm{dL}$. End-stage renal disease (on dialysis) was diagnosed with nephropathy when they presented with proteinuria, hypertension, DR and no signs of other renal diseases.

\section{Statistical analysis}

Unpaired Student's t test, Mann-Whitney U test, chi-square $\left(\chi^{2}\right)$ test and one-way analysis of variance (ANOVA) were used for comparison of parametric and non-parametric variables. Multiple logistic regression models were used to evaluate possible risk factors for neuropathy (dependent variable) and to identify potential confounding variables. Independent variables in these models were selected according to statistical significance by univariate analyses and to biological relevance. Results are presented as mean \pm standard deviation, as median (range) for variables without a normal distribution, or as percentage of patients that had the characteristic under analysis. $\mathrm{p}<0.05$ (two-tailed) were considered statistically significant. Calculations were performed using the software SPSS 10.0 and EPI INFO 6.04d.

\section{RESULTS}

The 340 patients, included in this study had the following general characteristics: age $=57.8 \pm 11$ years; duration of diabetes $=8 \pm 6.7$ years; BMI $29.3 \pm 5.3$ $\mathrm{kg} / \mathrm{m}^{2}$; WHR $0.96 \pm 0.07$; sex $=60 \%$ female. The frequency of use of insulin alone or together with oral agents was $47 \%$; $17 \%$ of the patients were smokers and $65.8 \%$ had hypertension. Diabetic nephropathy was diagnosed in $92(29.5 \%)$ patients, renal failure, in nine $(2.7 \%)$, and retinopathy, in $97(28.8 \%)$.
More than half of the patients had an unfavorable lipid profile demonstrated by total cholesterol levels higher than $200 \mathrm{mg} / \mathrm{dL}$ in $59 \%$, LDL higher than $100 \mathrm{mg} / \mathrm{dL}$ in $78.5 \%$, HDL lower than $45 \mathrm{mg} / \mathrm{dL}$ in $60 \%$, and triglycerides higher than $150 \mathrm{mg} / \mathrm{dL}$ in $55 \%$.

The Michigan questionnaire identified twice as many $(46 \%)$ patients with diabetic neuropathy as the physical examination $(22 \%)$, but the physical examination was more sensitive in diagnosing PDN (Michigan questionnaire: sensitivity $67 \%$, specificity $77 \%$, and physical examination: sensitivity $83 \%$, specificity $91 \%$ ). Therefore, only the neurological examination was used to establish a diagnosis of PDN.

Seventy-five patients $(22 \%)$ were diagnosed with diabetic neuropathy. These patients were older, had DM and used insulin for longer time. The values of $\mathrm{HbA}_{\mathrm{lc}}$, urea, creatinine, and microalbuminuria were higher for patients with neuropathy. No differences were found when BMI, WHR, HDL, LDL, total cholesterol, triglycerides, systolic and diastolic blood pressure values were compared between the two groups of patients (table 1 ).

Neuropathy was significantly associated with male sex (chi-square $5.4 ; \mathrm{p}=0.019$ ), positive answer to Michigan questionnaire (chi-square 23.4; $\mathrm{p}<0.001$ ), history of intermittent claudication (chi-square $15.4 ; \mathrm{p}<0.001$ ), no posterior tibial pulses (chi-square $=6.2 ; \mathrm{p}=0.013$ ), $\mathrm{HbA}_{\mathrm{lc}}>7 \%$ (chi-square $\left.5.5 ; \mathrm{p}=0.019\right)$, any degree of DR (chi-square $21 ; \mathrm{p}<0.001$ ). There were no significant associations between neuropathy and hypertension, use of alcohol, body weight or shape, or ethnicity.

A logistic regression model was used to investigate which characteristics were determinant to the development of neuropathy. The dependent variable was neuropathy and the independent variables were sex, age, duration of DM, HbAlc, renal failure, and retinopathy. The duration of $\mathrm{DM}(\mathrm{p}=0.001)$, renal failure $(\mathrm{p}=0.039)$, and $\mathrm{HbA}_{\mathrm{lc}}(\mathrm{p}=0.05)$ were significantly associated with neuropathy (table 2 ).

Diabetic nephropathy was diagnosed in 92 (29.5\%) patients (microalbuminuria 19.2\%, macroalbuminuria $3.2 \%$, proteinuria $7.1 \%$ ). Nine patients had renal failure; almost half of these patients $(44 \%)$ had neuropathy, whereas only $16.4 \%$ of those without microalbuminuria had neuropathy (chi-square = 18.7; $\mathrm{p}<0.001)$. Age, BMI, WHR, HDL, and LDL were similar in the three groups. The frequency of neuropathy was significantly greater for 19 patients with moderate renal impairment (creatinine $>1.4$ to 1.9 $\mathrm{mg} / \mathrm{dL}$ ) and seven with renal failure (creatinine $\geq 2$ $\mathrm{mg} / \mathrm{dl}$ ) (chi-square 17 and 66) than for those with normal creatinine concentrations $(\mathrm{p}<0.001)$. 
Table 1. Clinical characteristics and laboratory findings of 340 studied patients, and for patients with and without neuropathy (results are mean \pm standard deviation).

\begin{tabular}{|c|c|c|c|c|}
\hline Variable & $\begin{array}{c}\text { All patients } \\
(n=340)\end{array}$ & $\begin{array}{c}\text { With } \\
\text { neuropathy } \\
\text { (n = 75) }\end{array}$ & $\begin{array}{c}\text { Without } \\
\text { neuropathy } \\
\text { (n = 265) }\end{array}$ & p \\
\hline Age (years) & $57.8 \pm 11$ & $68.3 \pm 10.8$ & $57 \pm 11$ & $p=0.025$ \\
\hline $\operatorname{Sex}(m / f)$ & $137 / 203$ & $39 / 36$ & $98 / 167$ & $p=0.02$ \\
\hline Duration of diabetes (years) & $8 \pm 7$ & $11.7 \pm 7$ & $7 \pm 6.4$ & $p<0.001$ \\
\hline BMI $\left(\mathrm{kg} / \mathrm{m}^{2}\right)$ & $29.3 \pm 5.3$ & $28.5 \pm 5$ & $29.6 \pm 5$ & NS \\
\hline Systolic BP (mmHg) & $138.9 \pm 25$ & $141 \pm 27$ & $138 \pm 24$ & NS \\
\hline Diastolic BP $(\mathrm{mmHg})$ & $85 \pm 13$ & $84 \pm 14$ & $86 \pm 13$ & NS \\
\hline WHR & $0.96 \pm 0.07$ & $0.97 \pm 0.06$ & $0.96 \pm 0.07$ & NS \\
\hline Glucose (mg/dl) & $192 \pm 75.3$ & $199 \pm 73$ & $190 \pm 76$ & NS \\
\hline Hemoglobin A1C (\%) & $8.1 \pm 2.09$ & $8.5 \pm 2$ & $7.9 \pm 2$ & $p=0.049$ \\
\hline Total cholesterol (mg/dl) & $218 \pm 53$ & $216 \pm 51$ & $218 \pm 54$ & NS \\
\hline HDL cholesterol (mg/dl) & $43 \pm 11$ & $42 \pm 10$ & $44 \pm 11$ & NS \\
\hline LDL cholesterol (mg/dl) & $136 \pm 57$ & $144 \pm 86$ & $140 \pm 46$ & NS \\
\hline Triglycerides (mg/dl) & $210 \pm 175$ & $224 \pm 220$ & $206 \pm 160$ & NS \\
\hline Urea (mg/dl) & $37.2 \pm 18.1$ & $46 \pm 31$ & $35 \pm 11$ & $p<0.001$ \\
\hline Creatinine (mg/dl) & $1.11 \pm 0.51$ & $1.3 \pm 0.9$ & $1.1 \pm 0.3$ & $p<0.001$ \\
\hline Microalbuminuria $(\mathrm{mg} / \mathrm{l})^{*}$ & $104.3 \pm 346$ & $189.5 \pm 475.4$ & $80.2 \pm 296.2$ & $p=0.02$ \\
\hline
\end{tabular}

$\mathrm{BMI}=$ Body Mass Index, $\mathrm{WHR}=$ Waist to hip ratio. * Data for 312 patients.

Table 2. Logistic regression using neuropathy as a dependent variable, and sex, age, HbA1c, diabetes duration, renal insufficiency (creatinine > $2 \mathrm{mg} / \mathrm{dL}$ ), and retinopathy as independent variables.

\begin{tabular}{lcccc}
\hline Variables & B & SE & Significance & Exp(B) \\
Sex & 0.436 & 0.306 & 0.153 & 1.547 \\
Age & 0.015 & 0.015 & 0.311 & 1.015 \\
Hgb A1c & 0.142 & 0.072 & 0.050 & 1.152 \\
Renal insufficiency & 1.829 & 0.854 & 0.039 & 6.229 \\
Retinopathy & 0.517 & 0.331 & 0.119 & 1.677 \\
DM duration & 0.071 & 0.023 & 0.001 & 1.074 \\
\hline
\end{tabular}

The eye examination showed that $71 \%$ of diabetic patients had a normal fundus and $28.8 \%$ had RD. Of those patients with $\mathrm{RD}, 72 \%$ had pre-proliferative lesions and $28 \%$, proliferative lesions. The prevalence of neuropathy was $50 \%$ for patients without retinopathy, $36 \%$ in patients with pre-proliferative, and $14 \%$ in proliferative retinopathy (chi-square 16; $\mathrm{p}<0.001$ ). The difference in the prevalence of neuropathy was also evident in the group of patients with retinopathy and abnormally high $\mathrm{HgA}_{\mathrm{lc}}(>7 \%)$ (Chi-square = $11.5 ; \mathrm{p}=0.003$ ).

The prevalence of neuropathy was not different between patients with or without hypertension, angina pectoris. The percentage of patients with neuropathy was found in patients with probable ischemia or infarctions (27\%) than patients with normal ECG findings $(17 \%)$, (chi-square $2.9 ; \mathrm{p}=0.08)$. There was a sig- nificant association between peripheral arterial disease $(\mathrm{PAD})$ and neuropathy (chi square $6.3 ; \mathrm{p}=0.012$ ): $60 \%$ of the patients with PAD had neuropathy.

Clinical examination in the diagnosis of neuropathy had a sensitivity of $83 \%$, specificity of $91 \%$, positive predictive value of $63 \%$, and negative predictive value of $90 \%$.

Sensitivity and specificity for the different tests were: monofilament test, $100 \%$ and $87 \%$; pinprick, $100 \%$ and $80 \%$; deep tendon reflex, $75 \%$ and $89 \%$; vibration sense test, $83 \%$ and $68 \%$; temperature sense test, $83 \%$ and $68 \%$; walking on heels, $100 \%$ and $67 \%$.

The association of two neurological tests was also assessed. Altogether, the association of the pinprick and monofilament tests showed a sensitivity of $100 \%$, a specificity of $61 \%$, a positive predictive value (PPV) of $60 \%$, and a negative predictive value (NPV) 
of $100 \%$. The combination of the pinprick test and the ankle reflex revealed a sensitivity of $85 \%$, a specificity of $61 \%$, PPV of $63 \%$ and NPV of $84 \%$, whereas the combination of the monofilament test and the ankle reflex had a sensitivity of $92 \%$, specificity of $63 \%$, PPV of $63 \%$, and NPV of $92 \%$.

Therefore, the association did not improve the sensitivity of the clinical examination in the diagnosis of neuropathy; however, using the monofilament test and the ankle reflex may be more appropriate, as these tests can be more easily applied.

\section{DISCUSSION}

Our study found a $22 \%$ prevalence rate of diabetic neuropathy, which is similar to the rate reported in the classic study by Pirart, who found $20 \%$ to $30 \%$ prevalence after 10 to 15 years of disease $(8)$. This prevalence rate was also found in other studies (17).

Our patients were comparable to other populations with DM2, which are characteristically obese and have hypertension, dyslipidemias, and coronary artery disease.

Sixty-six percent of our patients were hypertensive. Studies have shown that $40-50 \%$ of patients with DM2 are hypertensive. The higher prevalence of hypertension might be assigned to the large number of overweight or obese patients $(84 \%)$, or to a selection bias that might have resulted from the fact that our diabetes outpatient clinic centralizes the most severely affected patients.

One third of our patients had some degree of protein loss, which is maybe a sign of diabetic nephropathy. In the literature, the prevalence rate of nephropathy among patients with type 2 diabetes is about the same. Almost half of patients with microalbuminuria had neuropathy $(18,19)$. Hypertension has also been shown to be an independent risk factor for the development and progression of nephropathy (20), retinopathy (21), and, more recently, neuropathy. This association suggests that vascular dysfunctions may be a common mechanism underlying all the long-term complications of diabetes.

Cigarette smoking increases the risk for diabetic nephropathy, retinopathy, and neuropathy, probably because of its metabolic effects in combination with increased inflammation and endothelial dysfunction (22). The fact that no difference in the prevalence of neuropathy among smokers, ex-smokers, and nonsmokers was found in this study may be explained by the low percentage of current smokers.
The positive association between $\mathrm{HbA}_{1 \mathrm{c}}$, blood urea nitrogen (BUN), and creatinine levels and neuropathy has been reported in several other studies (23). These associations were also found in this study after controlling for sex, age, and retinopathy. Duration of diabetes $(\mathrm{p}=0.001)$, renal failure $(\mathrm{p}=0.039)$ and $\mathrm{HbA}_{\mathrm{lc}}(\mathrm{p}=0.05)$ were found to be significantly associated with neuropathy.

Sixty-two patients (18.2\%) had peripheral artery disease, and this macrovascular complication was associated with an increased number of individuals with neuropathy. Our group described this association recently (24). It has already been described that impairment in motor nerve conduction velocity and pressure perception threshold are associated with the development of ulceration and lower limb amputation (25).

In conclusion, this study showed one fifth percent of DM2 patient of the city of Passo Fundo, South of Brazil. The physical examination is a more accurate method of diagnosis of peripheral neuropathy. Physical examination consists of monofilament, pinprick and deep tendon reflex tests. The association of the monofilament test and the ankle reflex was practical and accurate enough to be used in clinical grounds. $\mathrm{PDN}$ is associated with duration of diabetes, renal function, and diabetes control. PDN is also associated with other diabetic microvascular complications, such as retinopathy, nephropathy, and peripheral artery disease, but not with ischemic heart disease.

\section{REFERENCES}

1. Sheerwin R. Diabetes mellitus. In: Goldman L, Bennett JC (eds). Cecil Textbook of Medicine. Philadelphia: WB Saunders, 2000. pp. 1263-85

2. The Expert Committee on the Diagnosis and Classification of Diabetes Mellitus. Report of the Expert Committee on the Diagnosis and Classification of Diabetes Mellitus. Diabetes Care 2001;24(1):S5-20.

3. Fauci AS, Braunwald E, Isselbacher KJ, Kasper DL, Hauser SL, Longo DL, et al. Late Complications of Diabetes. New York: McGraw-Hill, 2001.

4. Associação Latinoamericana de Diabetes. Consenso ALAD. Prevenção, controle e tratamento do diabetes não insulinodependente. ALAD, 1995.

5. Malerbi DA, Franco LJ. The Brazilian Cooperative Group on the study on diabetes prevalence. Multicenter study of the prevalence of diabetes mellitus and impaired glucose in the urban Brazilian population aged 30-69 years. Diabetes Care 1992;15:1509-16.

6. American Diabetes Association, American Academy of Neurology. Consensus statement report and recommendations of the San Antonio Conference on Diabetic Neuropathy. Diabetes Care 1988;11:592-7.

7. Jeffcoate WJ, Harding KG. Diabetic foot ulcers. Lancet 2003;361:1545-51.

8. Pirart J. Diabetes mellitus and its degenerative complications: a prospective study of 4,400 patients observed between 1947 and 1973. Diabetes Care 1978;1:168-88, 252-63. 
9. Grimaldi A, Grange V, Allannic H, Passa P, Rodier M, Cornet $\mathrm{P}$, et al. Epidemiological analysis of patient with type 2 diabetes in France. J Diabetes Complications 2000;14:247-9.

10. Jaspan JB, Green AJ. The neuropathies of diabetes. In: DeGroot LJ, Besser M (eds). Endocrinology. Philadelphia: WB Saunders, 1995. p. 1545.

11. Boulton AJ. Guidelines for diagnosis and outpatient management of diabetic peripheral neuropathy. European Association for the Study of Diabetes, Neurodiab. Diabetes Metab 1998;24(suppl 3):55-65.

12. Stevens MJ, Feldman EL, Greene DA. The aetiology of diabetic neuropathy: the combined roles of metabolic and vascular defects. Diabet Med 1995;12:566-79.

13. Feldman EL, Stevens MJ, Thomas PK, Brown MB, Canal N, Greene DA. A practical two-step quantitative clinical and electrophysiological assessment for the diagnosis and staging of diabetic neuropathy. Diabetes Care 1996;17:1281-9.

14. Kandel ER, Schwartz JH, Jessel TM. Principles of neurology science. In: Dumitru D. Electrodiagnostic Medicine. New York: McGraw-Hill, 2000. pp. 730-1.

15. Rose G, Blackburn H, Gillum R, Prineas R. Cardiovascular survey methods. WHO Monograph Series 1982;56:123-9.

16. Zelmanovitz T, Gross JL, Oliveira J, Azevedo MJ. Proteinuria is still useful for the screening and diagnosis of overt diabetic nephropathy. Diabetes Care 1998;21:1076-9.

17. Comi G, Corbo M. Metabolic neuropathies. Curr Opin Neurol 1998; $11(5): 523-9$.

18. Savage S, Estacio RO, Jeffers B, Schrier RW. Urinary albumin excretion as a predictor of diabetic retinopathy, neuropathy and cardiovascular disease in NIDDM. Diabetes Care 1996; 19:1243-8.

19. Tesfaye S, Stevens LK, Stephenson JM, Fuller JH, Plater M, lonescu-Tirgoviste $\mathrm{C}$, et al. Prevalence of diabetic peripheral neuropathy and its relation to glycaemic control and potential risk factors: the EURODIAB IDDM complications study. Diabetologia 1996;39:1377-84.
20. Gall M-A, Borch-Johnsen K, Hougaard P, Nielsen FS, Parving $\mathrm{H}-\mathrm{H}$. Albuminuria and poor glycaemic control predict mortality in NIDDM. Diabetes 1995;44:1303-9.

21. Janka HU, Warram JH, Rand LJ, Krolewski AS. Risk factors for the progression of background retinopathy in long standing IDDM. Diabetes 1989;38:460-4.

22. Eliasson B. Cigarette smoking and diabetes. Prog Cardiovasc Dis 2003;45(5):405-13.

23. Jaspan JB, Green AJ. The neuropathies of diabetes. In: DeGroot LJ, Besser M, Burguer HG, Jameson JL, Loriaux DL, Marshall JC, et al. (eds). Endocrinology. $3^{\text {rd }}$ ed. Philadelphia: WB Saunders, 1995. pp. 1536-68.

24. Costa LA, Canani LH, Lisboa HR, Tres GS, Gross JL. Aggregation of features of the metabolic syndrome is associated with increased prevalence of chronic complications in type 2 diabetes. Diabet Med 2004;21(3):252-5.

25. Carrington AL, Shaw JE, Van Schie CH, Abbott CA, Vileikyte L, Boulton AJ. Can motor nerve conduction velocity predict foot problems in diabetic subjects over a 6-year outcome period? Diabetes Care 2002;25(11):2010-5.

\section{Endereço para correspondência:}

Hugo R.K. Lisbôa

Rua Teixeira Soares 885/806

99010-901 Passo Fundo, RS

Fax: (54) 3311-1499

E-mail: hlisboa@via-rs.net 